\title{
POLITIK PENDIDIKAN PADA MASA NABI MUHAMMAD SAW.
}

\author{
Mursal Aziz \\ Sekolah Tinggi Ilmu Tarbiyah Al-Ittihadiyah Labuhan Batu Utara \\ Jln. Madrasah Islamiyah, Jln. Lintas Sumatera No. 210 Gunting Saga, Labuhan Batu Utara \\ mursalaziz7@gmail.com
}

\begin{abstract}
Abstraksi : Hubungan antara politik dan pendidikan di dalam Islam tidak dapat dipisahkan. Perkembangan kegiatan-kegiatan kependidikan banyak dipengaruhi oleh para pemimpin (penguasa) dan mereka memerlukan dukungan institusiinstitusi pendidikan untuk mensukseskan kepemimpinannya. Politik pendidikan merupakan strategi pendidikan yang dirancang dalam upaya menciptakan kualitas sumberdaya manusia (human resources) yang unggul dan berkuwalitas. Pendidikan Islam berupaya membangun masyarakat yang sesuai dengan cita-cita ideologi Islam yang sesuai dengan Alquran dan hadis. Hal inilah yang dicontohkan oleh Nabi Muhammad saw. Pola pendidikan yang diterapkan oleh Nabi Muhammad saw. dalam sejarah sebagai bahan perbandingan, sumber gagasan, gambaran strategi dalam melaksanaan proses pendidikan Islam.
\end{abstract}

Kata Kunci: Politik, Pendidikan, Nabi Muhammad saw.

\section{Pendahuluan}

Pendidikan merupakan bagian kebutuhan mendasar manusia yang harus dimiliki oleh setiap manusia seperti pentingnya kesehatan, sandang, pangan, dan perumahan. Pendidikan tidak bisa dipisahkan dari masalah politik berdasarkan ideologi yang dianut oleh suatu daerah atau negara. Faktor ini sangat menentukan karakter dan tipologi masyarakat yang dibentuknya seperti apa yang telah dilakukan oleh Nabi Muhammad saw. di Makkah dan Madinah.

Politik pendidikan dapat dipahami sebagai strategi pendidikan yang dirancang negara dalam upaya menciptakan kualitas sumberdaya manusia (human resources) yang unggul. Pendidikan Islam berupaya membangun masyarakat yang sesuai dengan cita-cita ideologi Islam yang sesuai dengan Alquran dan hadis. Model masyarakat yang diciptakannya tentu saja akan berbeda dengan masyarakat yang dibentuk oleh kedua sistem ideologi sekular maupun komunis.

Pola pendidikan yang diterapkan oleh Nabi Muhammad saw. dalam sejarah perlu diungkapkan kembali, sebagai bahan perbandingan, sumber gagasan, gambaran strategi menyuseskan pelaksanaan proses pendidikan Islam. Pola 
pendidikan pada masa Nabi Muhammad saw. tidak terlepas dari pelaksanaan pendidikan Islam, baik secara teoritis maupun praktis, yang semua hal tersebut memiliki keterkaitan erat dengan politik pendidikan.

Pada tulisan ini akan dibahas mengenai politik pendidikan pada masa Nabi Muhammad saw. pembahasan ini sangat menarik sebagai bahan pertimbangan dalam mempelajari tantangan dan peluang politik pendidikan saat ini. Melalui tulisan ini akan diketahui bagaimana upaya langkah politik pendidikan yang pernah dilakukan Nabi Muhammad saw. sehingga sukses membangun peradaban yang memiliki akhlak mulia dan kuat dalam persatuan dimana pada waktu itu masyarakat masih jahiliyah dan suka berpecah belah. Kesuksesan Nabi Muhammad saw. dalam membangun pendidikan di daerah yang 'keras' merupakan kemampuan beliau dalam menerapkan politik pendidikan yang jitu yang perlu dicontoh dan diterapkan saat ini.

\section{Pembahasan}

\section{Politik Pendidikan}

Pendidikan dan politik adalah dua elemen penting dalam sistem sosial politik di setiap negara, baik negara maju maupun negara berkembang. Meskipun pendidikan dan politik berposisi sebagai dua elemen penting dalam sistem sosial politik, namun sering dikaji sebagai bagian-bagian yang terpisah. Politik dan pendidikan satu sama lain saling menunjang dan saling mengisi. Lembagalembaga dan proses pendidikan berperan penting dalam membentuk perilaku politik masyarakat sehingga membawa dampak besar pada karakteristik pendidikan di suatu negara. Politik dan pendidikan memiliki hubungan erat dan dinamis dimana hubungan tersebut adalah realitas empiris yang telah terjadi sejak awal perkembangan peradaban manusia dan menjadi perhatian para ilmuwan. ${ }^{1}$

Menurut Muhammad Daud Ali politik itu berasal dari bahasa latin Politicus atau bahasa Yunani Politicos yang artinya adalah sesuatu yang berhubungan dengan warga negara atau warga kota. ${ }^{2}$ Sedangkan menurut Kamus

\footnotetext{
${ }^{1}$ M. Sirozi, Politik Pendidikan (Jakarta: Rajawali Pers, 2010), h. 1.

2 Amnur, Konfigurasi Politik Pendidikan Nasional (Yogyakarta: Pustaka Fahima, 2007), h. 3 .
} 
Besar Bahasa Indonesia (KBBI), pengertian politik yaitu: (1) Pengetahuan tentang ketatanegaraan atau kenegaraan, yaitu mengenai sistem pemerintahan dan sebagainya; (2) segala urusan dan tindakan, kebijaksanaan, siasat dan sebagainya, tentang pemerintahan ataupun terhadap negara lain; (3) Kebijakan, cara bertindak di dalam menghadapi suatu masalah tertentu. Secara singkat dikatakan bahwa politik adalah suatu cara atau metode mempengaruhi orang atau pihak lain untuk mencapai tujuan kelompok. ${ }^{3}$

Adapun pendidikan merupakan proses pengubahan sikap dan tata laku seseorang atau kelompok orang dalam hal mendewasakan manusia melalui upaya pengajaran dan pelatihan. ${ }^{4}$ Pendidikan merupakan proses budaya untuk meningkatkan harkat dan martabat manusia sebagai makhluk sosial yang berlangsung sepanjang hayat. ${ }^{5}$

Imam Al-Ghazali sebagaimana dikutip oleh Muhammad 'Abdussalam al'Azmy juga menegaskan bahwa tujuan pendidikan itu adalah untuk membimbing para pelajar agar sampai pada pengenalan terhadap Allah swt. dan bersungguhsungguh dalam memanajemen dan melatih jiwa. ${ }^{6}$

Pendidikan adalah proses untuk membantu manusia dalam mengembangkan potensi yang ada di dalam dirinya. Potensi yang diberikan Allah swt. harus dikembangkan secara maksimal sehingga dapat menjalankan fungsinya sebagai 'abd Allah dan khaalifatun fil Ardh. Melalui pendidikan setiap individu dapat meningkatkan pengetahuan, kemampuan dan kreativitas terhadap perkembangan ilmu pengetahuan dan teknologi modern.

Berdasarkan uraian di atas dapat dipahami bahwa antara politik dan pendidikan memiliki keterkaitan erat yang tidak terpisahkan. Keterkaitan antara pendidikan dan politik dapat kita telusuri di dunia Islam, dimana sejarah peradaban Islam banyak ditandai oleh kesungguhan para ulama dan umara dalam memperhatikan persoalan pendidikan sebagai upaya untuk memperkuat posisi

${ }^{3}$ Ibid., h. 4.

${ }^{4}$ Syafaruddin et.al., Ilmu Pendidikan Islam: Melejitkan Potensi Budaya Umat (Jakarta: Hijri Pustaka Utama, 2012), h. 26.

${ }^{5}$ Syafaruddin, et.al., Sosiologi Pendidikan (Medan: Perdana Publishing, 2016), h. 95.

6 Muhammad Abdussalam al-'Azmy, Al-Tarbiyah al-Islamiyah: al-Ushul wa alTathbiqat, (Riyadh: Dar al-Nasir al-Dauly, 2006), h. 29 
sosial politik kelompok dan pengikutnya. Dalam analisis Rasyid (1994) tentang pendidikan pada masa Islam klasik dengan hasil kesimpulan dalam sejarah perkembangan Islam, Institusi politik ikut mewarnai corak pendidikan yang dikembangkan. Keterlibatan para penguasa dalam kegiatan pendidikan waktu itu, menurut Rasyid, tidak hanya sebatas dukungan moral kepada para peserta didik, melainkan juga dalam bidang administrasi, keuangan dan kurikulum. ${ }^{7}$

Para penguasa Islam senantiasa terlibat langsung dalam persoalan pendidikan. Pertama, karena Islam adalah agama yang totaliter jam 'i, mencakup semua aspek kehidupan seorang Muslim mulai dari makan dan minum, tatacara berumahtangga, urusan sosial kemasyarakatan, sampai pada ibadat semuanya diatur oleh syari'at. Untuk mengetahui bagaimana hidup yang Islami, seorang Muslim mesti terlibat dalam dunia pendidikan. Kedua, karena motivasi politik, sebab politik dan Agama sulit untuk dipisahkan dalam Islam. Para penguasa Muslim sering menjadikan kekuasaan sebagai alat untuk menanamkan pahampaham keagamaan. Inilah yang dilakukan oleh dinasti Buwaih, Fatimiyah dan Khalifah Al-Makmun. Dengan kekuasaan mereka menanamkan ideologi negara dengan tujuan lahirnya kesamaan ide antara penguasa dan masyarakat umum sehingga memudahkan pengaturan masalah-masalah kenegaraan.

Hubungan antara politik dan pendidikan di dalam Islam tampak sedemikian erat. Perkembangan kegiatan-kegiatan kependidikan banyak dipengaruhi oleh para penguasa dan para penguasa memerlukan dukungan institusi-institusi pendidikan untuk membenarkan dan mempertahankan kekuasaan mereka. Hal ini dapat dipahami, karena tujuan pemerintahan Islam, Menurut Abdul Ghaffar Aziz adalah menegakkan kebenaran dan keadilan. Tujuan itu tidak mungkin tercapai kecuali dengan melaksanakan syari'at yang akan berjalan apabila umat memahami ajaran Islam. ${ }^{8}$

Pendidikan sering dijadikan media dan wadah untuk menanamkan ideologi negara atau tulang yang menopang kerangka politik. Melalui inquisisi para ulama,

\footnotetext{
${ }^{7}$ Sirozi, Politik, h. 2.

${ }^{8}$ Ibid., h. 3.
} 
pilar penopang lembaga pendidikan dan pengembangan ilmu pengetahuan secara tidak langsung dipaksa menerima paham Mu'tazilah, ideologi resmi penguasa. ${ }^{9}$

Pendidikan dalam Islam harus kita pahami sebagai upaya mengubah manusia dengan pengetahuan tentang sikap dan perilaku yang sesuai dengan kerangka nilai ideologi Islam. Dengan demikian, pendidikan dalam Islam merupakan proses mendekatkan manusia pada tingkat kesempurnaannya dan mengembangkan kemampuannya yang dipandu oleh ideologi atau akidah Islam.

Politik pendidikan merupakan metode mempengaruhi pihak lain untuk mencapai tujuan pendidikan. Politik pendidikan juga berorientasi pada bagaimana pendidikan dapat dicapai dengan baik. Berbeda dengan pendidikan politik merupakan usaha sadar untuk menyiapkan peserta didik bagi perannya di dunia politik dan pendidikan politik ini juga menjadikan membuka mata manusia akan politik. ${ }^{10}$ Nabi Muhammad saw. ketika berdakwah lebih cenderung menerapkan prinsip-prinsip politik pendidikan sehingga dakwahnya dapat disampaikan secara luas tanpa batas wilayah dan beliau berhasil mendidik dengan baik para sahabat dan tabi'in serta sampai kepada saat ini.

\section{Sejarah Pendidikan Pada Masa Nabi Muhammad saw.}

Nabi Muhammad SAW. lahir pada hari Senin, 12 Rabiul awal 574 M, ${ }^{11}$ beliau besar di Makkah yang masyarakatnya sedang mengalami masa transisi yang hebat dalam berbagai bidang, seperti sosial, agama dan politik. Ajaran Islam yang dibawa oleh Nabi Muhammad saw. pada umumnya merupakan keinginan untuk memperbaiki dan menyelamatkan masyarakat Makkah dalam menjalani masa transisi ini. Nabi Muhammad saw. hadir pada waktu yang sangat tepat, pada saat itu manusia kehilangan pengetahuan dan keimanan mereka kepada Tuhan yang berhak disembah.

Nabi Muhammad saw. adalah utusan Allah swt. yang memiliki visi misi mulia dan istimewa. Allah swt. menyebutkan bahwa Nabi Muhammad saw. sebagai suri tauladan yang patut untuk dicontoh dan diidolakan kaum muslimin

\footnotetext{
9 Ibid., h. 4.

${ }^{10}$ Amnur, Konfigurasi, h. 5.

${ }^{11}$ K. Ali, Sejarah Islam (Tarikh Modern), (Jakarta: Srigantung, 1996), h.39.
} 
serta beliau sendiri juga menyatakan dalam hadisnya bahwa beliau diutus untuk menyempurnakan akhlak. Hal ini merupakan bentuk luhur yang luar biasa bagi Nabi Muhammad saw. dalam membeangun pendidikan di tengah tantangan zaman jahiliyah.

Nabi Muhammad saw. sebagai suri teladan dan rahmatan lil'alamin dan contoh pendidik pertama dan terutama dalam pendidikan Islam. Proses transformasi ilmu pengetahuan, internalisasi nilai-nilai spiritualisme dan bimbingan emosional yang dilakukan Rasulullah dapat dikatakan sebagai mukjizat luar biasa, yang manusia apa dan di mana pun tidak dapat melakukan hal yang sama. ${ }^{12}$

Kewajiban dakwah dan membangun pendidikan umat bermula ketika Nabi Muhammad saw. menerima wahyu pertama di Gua Hira', yaitu:

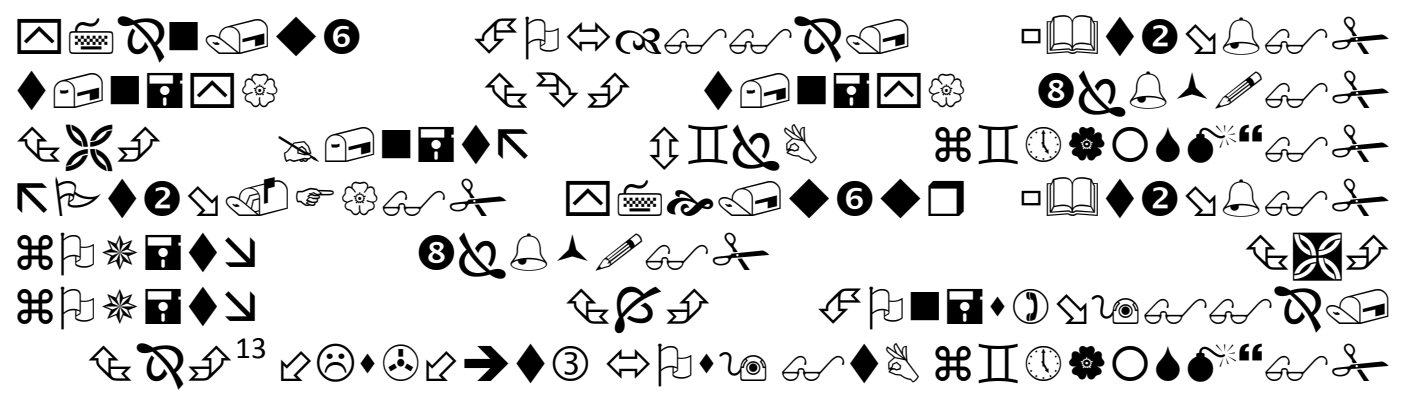

1. Bacalah dengan (menyebut) nama Tuhanmu yang Menciptakan, 2. Dia telah menciptakan manusia dari segumpal darah. 3. Bacalah, dan Tuhanmulah yang Maha pemurah, 4. Yang mengajar (manusia) dengan perantaran kalam, 5. Dia mengajar kepada manusia apa yang tidak diketahuinya.

Dalam tafsir Jalalain disebutkan bahwa Allah mengajarkan manusia menulis dengan memakai qalam dimana orang pertama yang menulis dengan memakai qalam atau pena adalah Nabi Idris as. Allah swt. mengajarkan manusia apa yang tidak diketahuinya yaitu sebelum Dia mengajarkan kepadanya hidayah, menulis dan berkreatif serta hal-hal lainnya. ${ }^{14}$

Awal dakwah Nabi Muhammad saw. dalam mengajarkan Islam kepada umatnya dengan cara sembunyi-sembunyi. Setelah banyak orang memeluk Islam,

\footnotetext{
${ }^{12}$ Fauzan Swito, Sejarah Pendidikan Islam (Jakarta: Kencana Prenata Media, 2005), h. 8.

${ }^{13}$ Q.S. Al-'Alaq/96: 1-5.

14 Imam Jalaluddin Al Mahalli dan Imam Jalaluddin As-Suyuti, Tafsir Jalalain Jilid 4 (Bandung: Sinar Baru Algesindo, 2015), h.2754.
} 
lalu Nabi Muhammad saw. menyediakan rumah Al-Arqam bin Abil Arqam sebagai tempat pertama pertemuan sahabat-sahabat dan pengikut-pengikutnya. Pada tahap awal pusat kegiatan pendidikan Islam diselenggarakan secara tersembunyi di rumah Arqam bin Abil Arqam. ${ }^{15}$ Nabi Muhammad saw. mengajarkan dasar-dasar atau pokok-pokok agama Islam kepada sahabatsahabatnya dan membacakan ayat-ayat Alquran sebagai wahyu dari Allah swt. yang harus disampaikan kepada para pengikutnya serta menerima tamu dan orang-orang yang ingin belajar dan berniat memeluk agama Islam atau menanyakan hal-hal yang berhubungan dengan agama Islam.

Pendidikan Islam pada masa Nabi Muhammad saw. berawal dari periode Makkah dan setelah hijrah berlanjut pada periode Madinah. Pada periode Makkah Nabi Muhammad lebih menitikberatkan pembinaan keimanan, moral dan akhlak kepada masyarakat Arab yang bermukim di Makkah. Sedangkan pada periode Madinah setelah hijrahnya, Nabi Muhammad saw. melakukan pembinaan di bidang muamalah serta sosial politik lainya sehingga lahirlah yang namanya Piagam Madinah. Bertitik tolak dari periode madinah inilah pendidikan Islam akhirnya berkembang sangat pesat hingga era dekade sekarang ini.

Dalam masa pembinaan pendidikan agama Islam di Makkah Nabi Muhammad juga mengajarkan Alquran karena Alquran merupakan inti sari dan sumber pokok ajaran Islam. Di samping itu Nabi Muhamad saw. mengajarkan tauhid kepada umatnya. ${ }^{16}$ Adapun pembinaan pendidikan Islam pada priode Makkah yang dilakukan oleh Rasulullah saw. lebih lanjut adalah meliputi:
a. Pendidikan Keagamaan,
b. Pendidikan Akliyah dan Ilmiah,
c. Pendidikan Akhlak dan Budi pekerti,
d. Pendidikan Jasmani atau Kesehatan. ${ }^{17}$

Adapun keterkaitan antara materi dan metode pendidikan Islam yang diajarkan oleh Nabi Muhammad saw. berkisar pada bidang keimanan, akhlak,

\footnotetext{
${ }^{15}$ Zuhairini et.al., Sejarah Pendidikan Islam (Jakarta: Bumi Aksara, 2008), h. 23.

${ }^{16}$ Ibid., h. 28.

${ }^{17}$ Zuhairini, et.al., Sejarah, h. 27.
} 
ibadah, kesehatan jasmanai dan pengetahuan kemasyarakatan yang dikembangkan oleh Nabi Muhammad saw. diantaranya yaitu:

a. Dalam bidang keimanan: bidang ini disampaikan melalui proses tanya jawab dengan penghayatan yang mendalam dan didukung oleh bukti-bukti yang rasional dan ilmiah yang diterima oleh umat Islam.

b. Materi ibadah: pada materi disampaikan oleh Nabi Muhammad saw. dengan metode demonstrasi dan peneladanan sehingga mudah didikuti masyarakat.

c. Bidang akhlak: pada bidang ini Nabi Muhammad saw. menitikberatkan pada metode peneladanan. Nabi tampil dalam kehidupan sebagai orang yang memiliki kemuliaan dan keagungan baik dalam ucapan maupun perbuatan. $^{18}$

Periode pendidikan yang dilakukan Nabi Muhammad saw. di Makkah berlanjut ke Madinah selama 10 tahun. Adapun letak perbedaan dua priode ini adalah kalau pada periode Makkah pendidikan memfokuskan pada penanaman aqidah dan yang berkaitan denganya, maka pada periode Madinah lebih merupakan penyempurnaan proses pendidikan terdahulu, yaitu pembinaan pendidikan difokuskan pada pendidikan sosial dan politik (dalam arti yang luas). Dalam hal ini, tujuan pendidikan yang dilakukan Nabi Muhammad saw. pada periode Madinah adalah pendidikan pribadi kader Islam yang diarahkan untuk membina aspek-aspek kemanusiaan dalam mengelola dan menjaga kesejahteraan alam semesta. ${ }^{19}$ Dengan kata lainya, periode madinah adalah periode spesialisasi pendidikan dalam beberapa bidang yang diperlukan untuk membangun peradaban baru yang berdasarkan pada tuntunan Alquran dan hadis (wahyu). ${ }^{20}$

Kegiatan dakwah dijalanka Nabi Muhammad saw. tanpa mengenal lelah. Usahanya yang gigih yang dilakukan beliau akhirnya berhasil sesuai yang diharapkan dengan jumlah pengikut nabi yang tadinya hanya belasan orang,

\footnotetext{
${ }^{18}$ Samsul Nizar, Sejarah Pendidikan Islam (Jakarta: Kencana, 2008), h. 93.

19 Abudin Nata, Sejarah Pendidikan Islam Pada Periode Klasik Dan Pertengahan (Jakarta: PT Raja grafindo, 2004), h. 2. 12.

${ }^{20}$ Machfud Seafuddin, Dinamika Peradapan Islam (Yogyakarta: Pustaka Ilmu, 2013), h.
} 
makin hari makin bertambah. Mereka terutama terdiri dari kaum wanita, budak, pekerja, dan orang-orang yang tak punya. Meskipun kebanyakan mereka orangorang yang lemah, namun semangat mereka sungguh membaja. ${ }^{21}$

Kurikulum pendidikan pada zaman Rasulullah saw. tidak mudah sebab Nabi Muhammad saw. mengajar kehidupan pada lembaga pendidikan yang luas tanpa di batasi dinding kelas dengan memanfaatkan berbagai kesempatan yang mengandung nilai-nilai pendidikan. Beliau menyampaikan ajarannya dimana saja seperti di rumah, di masjid, di jalan, dan di tempat-tempat lainnya.

\section{Politik Pendidikan Pada Masa Nabi Muhammad saw.}

Nabi Muhammad saw. adalah utusan Allah swt. yang pantas dan layak untuk dikagumi semua orang. Kemampuan luar biasa beliau dalam memimpin agama dan Negara bukan hanya dipandang indah oleh ummat Islam saja, tetapi orang yang berada di luar Islam juga mengakui kemampuan dan kehebatan Nabi Muhammad saw. Michael H Hart dalam buku 'The 100, A Ranking of the Most Influential Persons In History,' menempatkan Nabi Muhammad saw. dalam urutan pertama dari 100 orang paling berpengaruh di dunia mengalahkan tokohtokoh besar seperti: Isaac Newton, Paulus, dan Yesus. Menurut Michael H Hart, kebanyakan dari orang-orang besar yang ada dalam bukunya menjadi besar karena kebetulan lahir di negara-negara maju yang jadi pusat peradaban dunia. Bahkan tanpa ada mereka pun tetap saja negara-negara tersebut akan maju dan akan ada banyak orang yang akan menggantikannya untuk memimpin kemajuan tersebut. ${ }^{22}$ Hal ini menunjukkan bahwa Nabi Muhammad saw. menguasai dalam berbagai bidang termasuk masalah pendidikan dan politik pendidikan sehingga memiliki pengaruh yang sangat besar dalam pendidikan dan sektor lainnya dengan pola yang strategis.

Pada awal turunya wahyu pertama (the first revelation) yaitu Alquran surah al-'Alaq ayat 1-5 pola pendidikan yang dilakukan Nabi Muhammad saw.

21 Badri Yatim, Sejarah Peradaban Islam Dirasah Islamiyah II (Jakarta: PT Raja Grapindo Persada, 2004), h. 20.

${ }^{22}$ Michael H Hart, The 100, A Ranking of the Most Influential Persons In istory, Seratus Tokoh yang Paling Berpengaruh dalam Sejarah, Terjemahan H. Mahbub Djunaidi (Jakarta : Dunia Pustaka Jaya, 1982), h. 1. 
adalah secara sembunyi-sembunyi, mengingat kondisi sosial-politik yang belum stabil, dimulai dari dirinya sendiri dan keluarga dekatnya.

Nabi Muhammad saw. termasuk pendidik bagi para sahabat dan kaumnya. Salah satu contoh yang patut diteladani dari Nabi Muhammad saw. Adalah bahwa beliau tidak memisahkan permasalahan agama, pendidikan maupun sosial. Beliau dapat memberikan pencerahan bagi para sahabat maupun lingkungannya. Rasulullah adalah sosok yang menjadi contoh dan dan teladan, sebagaimana firman oleh Allah swt. ${ }^{23}$

Mulianya dan cerdasnya pribadi Nabi Muhammad saw. mengantarkan beliau untuk dijadikan contoh dan panutan dalam semua hal, termasuk dalam membangun proses pendidikan yang unggul. 'Abdullah Fattah Abu Ghuddah menyebutkan bahwa eksistensi dan posisi Nabi Muhammad saw. Dalam pendidikan termasuk sebagai sang edukator (pendidik, pengajar, guru) bagi seluruh umat manusia telah banyak diungkapkan dalam beberapa ayat dalam Alquran. ${ }^{24}$ Diantara ayat yang menyebutkan dengan jelas bahwa Rasulullah saw. Berperan penting dalam pendidikan termasuk sebagai pendidik adalah firman Allah swt. yaitu:

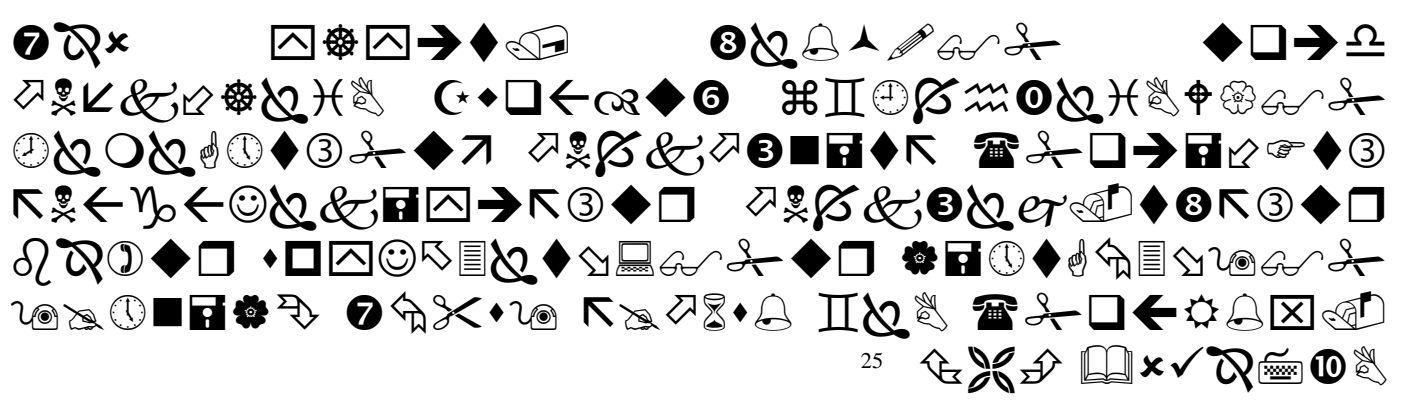

Dia-lah yang mengutus kepada kaum yang buta huruf seorang Rasul di antara mereka, yang membacakan ayat-ayat-Nya kepada mereka, mensucikan mereka dan mengajarkan mereka kitab dan Hikmah (As Sunnah). dan Sesungguhnya mereka sebelumnya benar-benar dalam kesesatan yang nyata,

Ayat di atas menjelaskan bahwa Allah swt. mengutus Nabi Muhammad saw. kepada kaum yang buta huruf yang memberikan pelajaran berupa kitab yaitu

${ }^{23}$ Q.S. Al-Mujadilah/58: 21.

24 Abdul Fattah Abu Ghuddah, Ar-Rosul Al-Mu'allim wa Asalibuhu fil Ta'lim, terj. Mochtar Zoerni, 40 Metode Pendidikan dan Pengajaran Rasulullah (Bandung: Irsyad Baitus Salam, 2012), h. 23.

${ }^{25}$ QS. Al-Jumu'ah/62: 2. 
Alquran dan hikmah (hadis). Eksistensi dan posisi Nabi Muhammad saw. sebagai sang educator (pendidik, pengajar, guru) termasuk keahlian dan kecerdasan dalam mengelola dengan baik peran politik pendidikan. Adapun esesnsi tugas para nabi dan Rasul sebagai pendidik yang ada di dalam Alquran pada dasarnya ada empat, yaitu:

1. membacakan ayat-ayat Allah yaitu Alquran (salah satu tugas Rasulullah adalah tabligh),

2. mentakziyah atau mensucikan diri manusia (beriman kepada Allah),

3. menta'lim atau mendidikkan al-Kitab dan al-Hikmah ke dalam diri manusia,

4. menta'lim atau mendidik kepada manusia hal-hal yang belum diketahui. ${ }^{26}$

Apabila diperhatikan sejarah atau tarikh dengan jelas, tidak pernah satu pendidikpun yang kesuksesannya dapat menandingi kesuksesan yang pernah diraih oleh Nabi Muhammad saw. dalam mendidik, membina, mengarahkan dan membangun generasi yang tidak memiliki pendidikan menjadi berpendidikan. Melalui pengelolaan pengajaran dan pendidikan yang beliau praktekkan, kemudian lahirlah generasi para sahabat dan tabi'in. Dengan keseriusan dan sikap terpuji beliau dalam dunia pendidikan, tentunya tidak mengherankan jika dalam waktu yang singkat Nabi Muhammad saw. mampu meraih kesuksesan yang gemilang dalam mendidik dan mengajar umat manusia.

Fakta sejarah membuktikan bahwa Nabi Muhammad saw. adalah pendidik yang sempurna yang ahli dan payawai dalam membangun pendidikan. Beliau merupakan sosok yang lebih mulia dibandingkan dengan tokoh-tokoh pendidikan yang lain yang telah popular dalam menggagas ide-ide dan temuan dunia dan sejarah pendidikan. Hal ini dibuktikan dengan pengajaran dan pendidikan yang beliau praktekkan, maka kemudian lahirlah generasi para sahabat dan tabi'in. Kesuksesan pengajaran beliau dapat dilihat dari perubahan dan transformasi pengetahuan yang mereka alami setelah mereka belajar kepada Nabi Muhammad

26 Al-Rasyidin, Falsafah Pendidikan Islami: Membangun Kerangka Ontologi, Epistimologi, dan aksiologi Praktik Pendidikan (Bandung: Citapustaka Media Perintis, 2012), h. 138. 
saw. Para sahabat adalah saksi dan bukti hidup atas keagungan pengajaran dan pendidikan beliau. ${ }^{27}$

Berdasarkan karakter pengajaran yang dicontohkan Nabi Muhammad saw. Dalam membangun pendidikan maka bukanlah perkara yang mustahil jika banyak orang yang menaruh perhatian dalam mempelajari ilmu pengetahuan, sehingga dalam waktu yang relatif singkat beliau akhirnya berhasil menciptakan suasana dan semangat belajar-mengajar yang kondusif di tengah-tengah masyarakat.

Sejarah telah mencatat bahwa proses pendidikan pada zaman Nabi Muhammad saw. ketika berada di Makkah belum berjalan sebagaimana yang diharapkan. Hal yang demikian belum di mungkinkan, karena pada saat itu Nabi Muhammmad saw. belum berperan sebagai pemimipin atau kepala Negara, bahkan beliau dan para pengikutnya berada dalam bayang-bayang ancaman pembunuhan dan kaum kafir Quraisy. Selama di Makkah pendidikan berlangsung dari rumah ke rumah secara sembunyi-sembunyi. Diantaranya yang terkenal adalah rumah Al-Arqam. Langkah yang bijak dilakukan Nabi Muhammad saw. pada tahap awal Islam ini adalah melarang para pengikutnya untuk menampakkan keislamannya dalam berbagai hal. Tidak menemui mereka kecuali dengan cara sembunyi-sembunyi dalam mendidik mereka.

Berbeda dengan periode di Makkah, pada periode Madinah Islam sudah memiliki kekuatan politik. Ajaran Islam yang berkenaan dengan kehidupan masyarakat banyak turun dan disampaikan di Madinah. Nabi Muhammad saw. juga mempunyai kedudukan, bukan saja sebagai pemimpin agama, tetapi juga sebagai kepala Negara yang memiliki power yang kuat serta disegani bahkan ditakuti kawan maupun lawan.

Setelah masyarakat Islam terbentuk di Madinah barulah pendidikan Islam dapat berjalan dengan leluasa dan terbuka secara umum dan kebijakan yang telah dilakukan Nabi Muhammmad saw. ketika di Madinah seperti: 1) membangun masjid di Madinah, 2) mempersatukan berbagai potensi yang semula saling berserakan bahkan saling bermusuhan. Langkah ini dituangkan dalam dokumen

\footnotetext{
${ }^{27}$ Ghuddah, Ar-Rosul Al-Mu'allim..., h. 28.
} 
yang lebih popular disebut piagam Madinah. Dengan adanya piagam tersebut terwujudlah keadaan masyarakat yang tenang, harmonis dan damai. ${ }^{28}$

Menurut M. Sirozi selain karena faktor religius bahwa agama Islam sangat menjunjung aktivitas kependidikan, perhatian besar para pemimpin Islam terhadap masalah pendidikan didorong oleh besarnya peran lembaga-lembaga pendidikan dalam penyampaian misi-misi politik. ${ }^{29}$ Hal tersebut juga dilakukan oleh Nabi Muhammad saw. Banyak upaya-upaya yang dilakukan oleh beliau dalam membangun politik pendidikan pada masanya. Adapun diantara upayaupaya politik pendidikan yang pernah dilakukan pada masa Nabi Muhammad saw. yaitu:

\section{a. Memperkuat persatuan dan mengikis permusuhan}

Nabi Muhammad saw. mengikis habis sisa-sisa permusuhan dan pertentangan antar suku, dengan jalan mengikat tali persaudaraan diantara mereka. Nabi mempersaudarakan dua-dua orang, mula-mula diantara sesama Muhajirin, kemudian diantara Muhajirin dan Anshar. Dengan lahirnya persaudaraan itu bertambah kokohlah persatuan kaum muslimin. ${ }^{30}$ Tugas Nabi Muhammad saw. daalam membina dan mengembangkan persatuan dan kesatuan masyaraka Islam yang baru tumbuh berhasil dengan baik, sehingga mewujudkan satu kesatuan sosial dan kesatuan politik.

Nabi Muhammad saw. mempersatukan berbagai potensi yang semula saling berserakan bahkan saling bermusuhan. Langkah ini dituangkan dalam dokumen yang lebih popular disebut piagam Madinah. Dengan adanya piagam tersebut terwujudlah keadaan masyarakat yang tenang, harmonis dan damai. ${ }^{31}$ Setelah selesai Nabi Muhammad saw. mempersatukan kaum muslimin, sehingga menjadi bersaudara, lalu Nabi mengadakan perjanjian dengan kaum Yahudi, penduduk Madinah.

\footnotetext{
${ }^{28}$ Zuhairini et.al., Sejarah, h. 87.

${ }^{29}$ Sirozi, Politik, h. 4.

${ }^{30}$ Mahmud Yunus, Sejarah Pendidikan Islam (Jakarta: PT.Raja Grafindo, Persada, 2008),

${ }^{31}$ Abuddin Nata, Pendidikan Islam Perspektif Hadits (Ciputat: UIN Jakarta Press, 2005),
} h. 26 . h. 24 . 
Perjanjian anatara Nabi Muhammad saw. (kaum muslimin) dan Yahudi Madinah merupakan bagian dari poltik pendidikan yang membantu mensukseskan dakwah Nabi Muhammad saw. Hal tersebut ditegaskan, bahwa kaum Yahudi bersahabat dengan kaum muslimin, tolong-menolong, bantu-membantu, terutama bila ada seranga musuh terhadap Madinah. Mereka harus memperhatikan negeri bersama-sama kaum Muslimin, di samping itu kaum Yahudi merdeka memeluk agamanya dan bebas beribadat menurut kepercayaannya. Inilah salah satu perjanjian persahabatan yang dilakukan oleh Nabi Muhammad saw. ${ }^{32}$ Dalam perjanjian tersebut tentunya menguntungkan berbagai pihak, termasuk umat Islam. Kemampuan Nabi Muhammad saw. membuat antara kaum muslimin dan kaum Yahudi bersahabat saling tolong-menolong, bantu-membantu dalam membangun kemanan. Mereka harus saling bersatu padu dalam membangun Madinah.

\section{b. Memanfaatkan tawanan perang untuk mengajar}

Perhatian Nabi Muhammad saw. terhadap dunia pendidikan tampak ketika beliau menetapkan para tawanan Perang Badar yang ingin bebas untuk mengajarkan baca-tulis kepada sepuluh orang penduduk Madinah sebagai tebusan atas diri mereka. Menurut hukum Islam, barang tebusan itu merupakan hak Baitul Mal (kas negara). Tebusan ini sama nilainya dengan pembebasan tawanan Perang Badar, artinya, dengan tindakan membebankan pembebasan tawanan Perang Badar pada Baitul Mal (kas negara). Hal ini menunjukkan kepedulian Nabi Muhammad saw. luar biasa dengan memerintahkan tawanan perang mengajarkan baca tulis yang berarti Rasulullah saw. telah menjadikan biaya pendidikan itu setara nilainya dengan barang tebusan. Dengan kata lain, beliau memberi upah kepada para pengajar itu (tawanan perang) dengan harta benda yang seharusnya menjadi milik kas negara.

\footnotetext{
${ }^{32}$ Yunus, Sejarah, h. 16.
} 


\section{c. Membangun masjid sebagai lembaga dan pusat persatuan}

Kebijakan pendidikan yang dilakukan Nabi Muhammad saw. banyak sekali, diantaranya adalah pada masa periode Madinah beliau membangun masjid di Madinah. Upaya ini dilakukan untuk mempersatukan berbagai potensi yang semula saling berserakan bahkan saling bermusuhan. Langkah ini dituangkan dalam dokumen yang lebih popular disebut piagam Madinah. Pokok pembinaan pendidikan Islam di kota Madinah dapat dikatakan sebagai pendidikan sosial dan politik yang disinari nilai-nilai tauhid. ${ }^{33}$ Upaya politik pendidikan yang dilakukan Nabi Muhammad saw. ini merupakan hal yang sangat strategis dan sangat menentukan, karena masjid pada waktu itu termasuk bagian dari lembaga pendidikan dan melalui masjid ini Nabi mengembangkan pendidikan Islam.

Membangun masjid di Madinah merupakan upaya dalam pembentukan dan pembinaan masyarakat baru menuju satu kesatuan sosial dan politik. Masjid ini berperan sangat urgen dan selanjutnya digunakan sebagai pusat kegiatan pendidikan dan dakwah. Masjid juga adalah bagian upaya dalam mempersatukan berbagai potensi yang semula saling berserakan bahkan saling bermusuhan. Langkah ini dituangkan dalam dokumen yang lebih popular disebut piagam Madinah. Dengan adanya piagam tersebut terwujudlah keadaan masyarakat yang tenang, harmonis dan damai.

\section{d. Penyetaraan semua golongan dan pemakmuran rakyat}

Untuk menjalin kerjasama dan saling menolong, turunlah syari'at zakat dan puasa yang merupakan pendidikan bagi warga masyarakat dalam tanggung jawab sosial. Disyaria'atkannya media komunikasi berdasarkan wahyu, yaitu shalat jum'at yang dilaksanakan secara berjama'ah. Rasa memiliki kebanggaan sosial tersebut lebih mendalam lagi setelah Nabi Muhammad saw. mendapat izin dari Allah untuk memindahkan kiblat dalam shalat dari baitul Maqdis ke Baitul Haram di Makkah. ${ }^{34}$

\footnotetext{
${ }^{33}$ Surawardi, "Sistem dan Kelembagaan Pendidikan Islam Periode Madinah," dalam Management of Education, Vol. 1, ISSN 977-2442404, h. 103.

${ }^{34}$ Zuhairini et.al., Sejarah, h. 35-37.
} 
Langkah lain yang diambil oleh Nabi Muhammad saw. adalah menyeru masyarakat secara umum. Beliau mulai menyeru segala lapisan masyarakat kepada Islam terang-terangan, baik golongan bangsawan maupun hambah sahaya tanpa membedakan status sosial maupun politik. Mula-mula beliau menyeru penduduk Makkah, kemudian penduduk negeri-negeri lain. Di samping itu, beliau juga menyeru orang-orang yang datang ke Makkah dari berbagai negeri untuk mengerjakan haji. Kegiatan dakwah dijalankannya tanpa mengenal lelah, dengan usaha yang gigih akhirnya Nabi Muhammad saw. menemui hasil yang diharapkan.

\section{Kesimpulan}

Hubungan antara politik dan pendidikan di dalam Islam tampak sedemikian erat. Perkembangan kegiatan-kegiatan kependidikan banyak dipengaruhi oleh para penguasa dan para penguasa memerlukan dukungan institusi-institusi pendidikan untuk membenarkan dan mempertahankan kekuasaan mereka. Pola pendidikan yang diterapkan oleh Nabi Muhammad saw. dalam sejarah perlu diungkapkan kembali, sebagai bahan perbandingan, sumber gagasan, gambaran strategi menyuseskan pelaksanaan proses pendidikan Islam.

Pendidikan Islam pada masa Nabi Muhammad saw. berawal dari periode Makkah dan setelah hijrah berlanjut pada periode Madinah. Pada periode Makkah Nabi Muhammad lebih menitikberatkan pembinaan keimanan, moral dan akhlak kepada masyarakat Arab yang bermukim di Makkah. Sedangkan pada periode Madinah setelah hijrahnya, Nabi Muhammad saw. melakukan pembinaan di bidang muamalah serta sosial politik lainya sehingga lahirlah yang namanya Piagam Madinah. Bertitik tolak dari periode madinah inilah pendidikan Islam akhirnya berkembang sangat pesat hingga era dekade sekarang ini.

Setelah masyarakat Islam terbentuk di Madinah pendidikan Islam dapat berjalan dengan leluasa dan terbuka secara umum dan kebijakan yang telah dilakukan Nabi Muhammmad saw. ketika di Madinah seperti: 1) membangun masjid di Madinah, 2) mempersatukan berbagai potensi yang semula saling berserakan bahkan saling bermusuhan. Langkah ini dituangkan dalam dokumen 
yang lebih popular disebut piagam Madinah. Dengan adanya piagam tersebut terwujudlah keadaan masyarakat yang tenang, harmonis dan damai.

\section{Pustaka Acuan}

Al Mahalli, Imam Jalaluddin dan Imam Jalaluddin As-Suyuti, Tafsir Jalalain Jilid 4, Bandung: Sinar Baru Algesindo, 2015.

al-'Azmy, Muhammad Abdussalam. Al-Tarbiyah al-Islamiyah: al-Ushul wa alTathbiqat, Riyadh: Dar al-Nasir al-Dauly, 2006.

Ali, K. Sejarah Islam (Tarikh Modern), Jakarta: Srigantung, 1996.

Al-Rasyidin. Falsafah Pendidikan Islami: Membangun Kerangka Ontologi, Epistimologi, dan aksiologi Praktik Pendidikan, Bandung: Citapustaka Media Perintis, 2012.

Amnur, Konfigurasi Politik Pendidikan Nasional, Yogyakarta: Pustaka Fahima, 2007.

Ghuddah, Abdul Fattah Abu. Ar-Rosul Al-Mu'allim wa Asalibuhu fil Ta'lim, terj. Mochtar Zoerni, 40 Metode Pendidikan dan Pengajaran Rasulullah, Bandung: Irsyad Baitus Salam, 2012.

Hart, Michael H. The 100, A Ranking of the Most Influential Persons In istory, Seratus Tokoh yang Paling Berpengaruh dalam Sejarah, Terjemahan H. Mahbub Djunaidi, Jakarta: Dunia Pustaka Jaya, 1982.

Nata, Abuddin. Pendidikan Islam Perspektif Hadits, Ciputat: UIN Jakarta Press, 2005.

Nata, Abudin. Sejarah Pendidikan Islam Pada Periode Klasik Dan Pertengahan, Jakarta: PT Raja grafindo, 2004.

Nizar, Samsul. Sejarah Pendidikan Islam, Jakarta: Kencana, 2008.

Seafuddin, Machfud. Dinamika Peradapan Islam, Yogyakarta: Pustaka Ilmu, 2013.

Sirozi, M., Politik Pendidikan, Jakarta: Rajawali Pers, 2010.

Surawardi, "Sistem dan Kelembagaan Pendidikan Islam Periode Madinah," dalam Management of Education, Vol. 1, ISSN 977-2442404.

Swito, Fauzan. Sejarah Pendidikan Islam, Jakarta: Kencana Prenata Media, 2005.

Syafaruddin et.al., Ilmu Pendidikan Islam: Melejitkan Potensi Budaya Umat, Jakarta: Hijri Pustaka Utama, 2012.

Syafaruddin, et.al., Sosiologi Pendidikan, Medan: Perdana Publishing, 2016. 
Yatim, Badri. Sejarah Peradaban Islam Dirasah Islamiyah II (Jakarta: PT Raja Grapindo Persada, 2004.

Yunus, Mahmud. Sejarah Pendidikan Islam, Jakarta: PT.Raja Grafindo, Persada, 2008.

Zuhairini et.al., Sejarah Pendidikan Islam, Jakarta: Bumi Aksara, 2008. 